\title{
PENGARUH KUALITAS PELAYANAN ADMINISTRASI AKADEMIK DAN KEMAHASISWAAN TERHADAP KEPUASAN MAHASISWA FAKULTAS EKONOMI DAN BISNIS ISLAM IAIN BENGKULU
}

\author{
Yenti Sumarni \\ FEBI IAIN Bengkulu \\ E-mail: iyent_mr@ymail.com
}

\begin{abstract}
This study aimed to analyze the quality of academic administration and students services in IAIN Bengkulu. The sampling technique was done by using purposive sampling, where in this case, the selected respondents are students who use the services of Academic Administration and Student Affairs who are active students from the beginning until the end of the semester with a sample size obtained that consists of 100 respondents. The data analysis was performed by using multiple linear regression analysis results from several related quality of academic administrative services obtained that the better the quality of Academic and Student Administration services, the higher satisfaction of students of the Faculty of Islamic Economy will be.
\end{abstract}

Keyword: Academic Administration and Student Affairs, Service Quality,Students Satisfaction

PENDAHULUAN

Era globalisasi merupakan tantangan tersendiri bagi Perguruan Tinggi dalam menyiapkan lulusannya agar mampu berkompetisi dalam memperebutkan pasar kerja dan menghasilkan lulusan yang inovatif dan kreatif. Hal ini berarti persaingan tenaga kerja akan terbuka, konsekuensinya tenaga kerja kita harus mampu bersaing secara terbuka dengan tenaga kerja asing dari berbagai negara.
Peranan pendidikan dalam kehidupan sangat penting. Di bidang pendidikan tinggi, tantangan dan persaingan semakin berat dan kompleks yang diakibatkan oleh ekspansi pasar internasional dalam dunia pendidikan di satu sisi dan dinamika internal pendidikan dalam negeri di sisi lain. Salah satu kunci untuk memenangkan persaingan dalam dunia pendidikan tinggi di era globalisasi saat ini adalah dengan berusaha meningkatkan rasa kepuasan konsumen terhadap jasa/layanan 
yang diberikan pihak universitas kepada mahasiswanya ${ }^{1}$. Salah satu bentuk pelayanan sebuah perguruan tinggi adalah pelayanan administrasi akademik.

Mahasiswa merupakan pelanggan atau konsumen bagi institusi pendidikan tinggi. Institusi sudah seharusnya dapat menjamin kepuasan mahasiswa, tidak hanya dalam proses belajar mengajar, tetapi mencakup pula dalam pelayanan administrasinya proses administrasi akademik merupakan oleh mahasiswa ketika ditanya bagaimana kualitas pelayanan di sebuah perguruan tinggi, maka yang dinilainya adalah pelayanan administrasi akademik, Paradigma baru manajemen pendidikan tinggi merujuk pada lima pilar: kualitas, otonomi, akuntabilitas, akreditasi, dan evaluasi (Dirjen Dikti, 1990). Pemberlakuan paradigma tersebut berfungsi untuk mewujudkan tujuan akhir peningkatan kualitas secara berkelanjutan. Manajemen peningkatan mutu pendidikan tinggi diartikan sebagai layanan profesional publik yang dijalankan dan diarahkan semaksimal mungkin untuk memberikan layanan yang sesuai atau melebihi standar. Artinya layanan yang diberikan perguruan tinggi harus berkualitas agar mendapatkan kepercayaan masyarakat

${ }^{1}$ Tjiptono,F. 2002, Strategi Pemasaran, Edisi.2, Cet.2, Andi Offset, Yogyakarta. hal.312 atau publik. Ini berarti setidaknya perguruan tinggi harus memiliki kriteria dan standar pelayanan atau melakukan pengukuran layanan kepada para pelanggan dalam rangka meningkatkan kualitas pendidikannya.

Sistem manajemen pengendalian mutu layanan perguruan tinggi terbagi dua, yaitu internal dan eksternal. Pada lingkup internal mencakup pengawasan penyelenggaraan pendidikan tinggi oleh perguruan tinggi guna mewujudkan visi misi serta untuk memenuhi kebutuhan pemegang kepentingan (pelanggan) melalui penyelenggaraan Tridharma Perguruan Tinggi. Lingkup eksternal saat ini lazim dilakukan melalui penilaian standar mutu oleh BAN PT (Badan Akreditasi Nasional Perguruan Tinggi) dan ISO (International Organization For Standardization).

Disebutkan pada salah satu prinsip ISO bahwa pengukuran kepuasan pelanggan wajib dilakukan sebagai umpan balik dari pelanggan terhadap sistem yang diterapkan. Ini berarti bahwa keberhasilan sebuah lembaga sangat ditentukan oleh mutu layanan yang diberikan. Pelayanan yang bermutu dapat diidentifikasikan melalui kepuasan pelanggan. Sebagai lembaga pendidikan maka proses akademik merupakan proses inti, oleh karena itu pengukuran kepuasan 
pelanggan pada proses ini wajib dilakukan secara periodik.

Berlandaskan pemahamam mutu diatas, dapat dikatakan bahwa saat ini pendidikan bukan lagi sebatas kemampuan untuk menghasilkan lulusan yang diukur secara akademik, tetapi sudah mengarah pada suatu bentuk kualitas pendidikan secara menyeluruh (Total Quality Education) yang berorientasi pada kepuasan pelanggan ${ }^{2}$. Pelanggan pendidikan terbagi ke dalam dua kelompok, yaitu pelanggan internal dan pelanggan eksternal. Pelanggan internal meliputi para pendidik dan staf pendukung. Pelanggan eksternal meliputi pelanggan eksternal utama adalah peserta didik; pelanggan eksternal sekunder adalah orang tua, pemerintah dan employers, serta pelanggan eksternal tersier adalah pasaran kerja, pemerintah dan masyarakat Pelanggan adalah orang-orang yang menggunakan atau memakai produk dari lembaga. Produk dapat berupa barang ataupun jasa.

Perguruan tinggi berkegiatan memberikan layanan pendidikan. Produk perguruan tinggi berupa ilmu pengetahuan dan pendidikan, dimanfaatkan atau digunakan oleh mahasiswa, dengan demikian mahasiswa

\footnotetext{
${ }^{2}$ Endang, Fatmawati. (2003). Analisis Kualitas Pelayanan Pada Bagian Administrasi Fakultas Ekonomi UNDIP. Tesis. Universitas Diponegoro. hal.123
}

adalah pelanggan. Ilmu pengetahuan dan pendidikan adalah sesuatu yang tidak kelihatan, maka perguruan tinggi dapat pula dipandang sebagai industri jasa. Industri jasa dalam mencapai keberhasilan dan kualitas layanan selama ini selalu berfokus pada pelanggan. Pada perguruan tinggi, maka usaha memenuhi kebutuhan mahasiswa harus menjadi fokus utama dalam mengelola mutu/kualitas layanan pendidikan.

Mahasiswa menjadi sangat penting selain sebagai pelanggan utama adalah karena keberhasilan proses belajar sangat tergantung dari partisipasi mahasiwa, betapapun pandainya para dosen yang mengajar. Sesuai dengan konsep manajemen mutu perguruan tinggi, bahwa pelaksanaan pendidikan harus melakukan monitoring dan evaluasi, maka perlu untuk mengetahui bagaimana kepuasan mahasiswa terhadap layanan yang sudah diberikan. Tentunya akan berpengaruh terhadap kualitas layanan pendidikan yang diberikan.

Pelayanan Administrasi Akademik dan Kemahasiswaan( AAK) IAIN Bengkulu terdiri dari tingkat Institut dan Fakultas, tingkat institut melayani semua mahasiswa IAIN Bengkulu.dalam pelaksanaan pelayanan dibagi menjadi Kasubag Sistem Informasi Akademik dan Kasubag Kemahasiswaan dan Alumni dan dipimpin kabag AAK. AAK 
Tingkat Institut melayani seluruh kegiatan administrasi akademik dan mahasiswa dimulai dari pendaftaran mahasiswa baru sampai pendaftaran mahasiswa wisuda dan pelayanan administrasi berhubungan dengan akademik melalui sistem layanan informasi akademik (SIAKAD) layanan yang diberikaan antara lain konsultasi mahasiswa tentang status keaktifan, Kartu Rencana Studi, Cetak kartu Tanda Mahasiswa (KTM)), permohonan beasiswa, permohonan suratl. 1. Kepuasan Pelanggan (mahasiswa) keterangan aktif kuliah, permohonan cuti studi dan yang lainnya. Seluruh mahasiswa IAIN Bengkulu mendapatkan pelayanan dari AAK khususnya mahasiswa Fakultas Ekonomi dan Bisnis Islam.

Berkaitan dengan fungsinya yang selalu berhubungan dengan mahasiswa, maka layanan akademik dianggap merupakan salah satu pendukung terwujudnya pendidikan yang berkualitas. Dengan demikian perlu adanya inovasi manajemen dan pengukuran atau evaluasi dari para pengguna jasa layanan (mahasiswa). AAK perlu mendukung misi IAIN Bengkulu diantaranya adalah meningkatkan mutu mahasiswa yang berkarakter, profesional, mandiri dan akhlak mulia untuk mendukung misi tersebut AAK perlu melakukan evaluasi kualitas pelayanan terhadap penggunanya untuk mengetahui kekurangandari pelayanan yang diberikan terutama bagian AAK terhadap mahasiswa sebagai mayoritas pengguna jasa pelayanan. Yang memberikan pelayanan yang ada di AAK harus peka terhadap keluhan mahasiswa. Keluhan mahasiswa akan mempengaruhi tingkat kepuasan mahasiswa sebagai penerima layanan administrasi akademik dan kemahasiswaan

\section{KAJIAN TEORI}

Kata kepuasan atau satisfaction berasal dari bahasa latin "satis" (artinya cukup baik, memadai) dan "facio" (melakukan atau membuat). Secara sederhana kepuasan dapat diartikan sebagai upaya pemenuhan sesuatu atau membuat sesuatu memadai. Konsep kepuasan pelanggan masih bersifat abstrak, meski demikian kepuasan pelanggan menjadi konsep sentral dalam teori dan praktik pemasaran, serta merupakan salah satu tujuan esensial bagi aktivitas bisnis $^{3}$ Pencapaian kepuasan dapat merupakan proses yang sederhana maupun kompleks.

Dalam hal ini peranan setiap individu dalam service encounter sangatlah penting dan berpengaruh terhadap kepuasan yang dibentuk. Sesuai dengan pendapat diatas istilah kepuasan jika ditinjau dari perilaku

\footnotetext{
${ }^{3}$ Fandy Tjiptono. (2002). Strategi Pemasaran.
} Yogyakarta: Penerbit Andi, hal 433 
konsumen menjadi sesuatu yang kompleks. Konsumen dalam memberikan penilaian sesuatu biasanya akan lebih kecewa terhadap jasa dibandingkan barang. Alasannya adalah karena mereka juga ikut terlibat dalam proses penciptaan jasa.

Kepuasan pelanggan adalah hasil yang dirasakan atas penggunaan produk atau jasa, yang dirasakan terhadap produk atau jasa tersebut sama atau melebihi harapan yang diinginkan oleh konsumen. Kepuasan pelanggan tercapai bila kebutuhan, keinginan, dan harapan pelanggan terpenuhi. Perusahaan harus berusaha mengetahui apa yang diharapkan pelanggan dari produk dan jasa yang dihasilkan. Harapan pelanggan dapat diidentifikasi secara tepat apabila perusahaan mengerti persepsi pelanggan terhadap kepuasan. Mengetahui persepsi pelanggan terhadap kepuasan sangatlah penting, agar tidak terjadi kesenjangan. Bila kinerja produk jauh lebih rendah dibandingkan harapan pelanggan, pembelinya tidak puas. Sebaliknya bila kinerja sesuai dengan harapan atau melebihi harapan, pembelinya merasa puas atau merasa merasa amat gembira ${ }^{4}$.

\footnotetext{
${ }^{4}$ Yanisma.(2010) Analisis Kepuasan Mahasiswa Terhadap Kualitas Layanan Pada Biro Admnistrasi Akademik Kemahasiwaan (Studi Kasus Mahasiswa Politeknik Negeri Bengkalis) DiaksesDarihttp://p3m.polbeng.ac.id/dataq/file_content/Fie
}

Tingkat kepuasan adalah fungsi dari perbedaan antara kinerja yang dirasakan dengan harapan ${ }^{5}$. Dengan demikian, harapan pelanggan melatar belakangi mengapa dua organisasi pada jenis bisnis yang sama dapat dinilai berbeda oleh pelanggannya. Dalam konteks kepuasan pelanggan, umumnya harapan merupakan perkiraan atau keyakinan pelanggan tentang apa yang akan diterimanya. Harapan mereka dibentuk oleh pengalaman pembelian dahulu, komentar teman dan kenalannya serta janji dari perusahaan tersebut. Harapan-harapan pelanggan ini dari waktu ke waktu berkembang seiring dengan semakin bertambahnya pengalaman pelanggan.

Berdasarkan beberapa pendapat diatas dapat dikatakan bahwa kepuasan adalah kesesuaian harapan atau hal yang dirasakan oleh pelanggan dengan perlakuan yang diterimanya ketika meminta layanan dari suatu lembaga. Ini berarti kepuasan pelanggan dipengaruhi oleh kinerja pegawai dalam memberikan layanan. Hal ini tentu berpengaruh terhadap eksistensi lembaga tersebut di mata pelanggannya. Upaya mewujudkan kepuasan pelanggan total tidak mungkin tercapai meskipun untuk sementara

\footnotetext{
${ }^{5}$ Kotler, Philip. 1997, Manajemen Pemasaran :Analisis, Perencanaan, Implementasi dan Kontrol, Ed. 9, Jilid 1, PT Prenhallindo, Jakarta hal.123
} 
waktu, namun upaya perbaikan atau penyempurnaan kepuasan dapat dilakukan dengan berbagai strategi. Pada prinsipnya strategi kepuasan pelanggan akan menyebabkan para pesaing harus bekerja keras dan memerlukan biaya tinggi dalam usahanya merebut pelanggan suatu perusahaan $^{6}$

\section{Kualitas Pelayanan}

Kualitas pelayanan/jasa, adalah tingkat keunggulan yang diharapkan dan pengendalian atas tingkat keunggulan tersebut untuk memenuhi keinginan pelanggan. Dengan demikian ada 2 faktor utama yang mempengaruhi kualitas pelayanan/jasa yaitu : expected service dan perceived Service. Apabila pelayanan (jasa) yang diterima atau dirasakan (perceived service) sesuai dengan yang diharapkan (expected service), maka kualitas jasa dipersepsikan baik dan memuaskan. Jika jasa yang diterima melampaui harapan pelanggan, maka kualitas jasa dipersepsikan sebagai kualitas yang ideal. Sebaliknya jika jasa yang di terima lebih rendah daripada yang di harapkan, maka kualitas jasa dipersepsikan buruk. Baik tidaknya kualitas jasa tergantung pada

\footnotetext{
${ }^{6}$ Tjiptono F Op.Cit., hal 160-161
}

penyedia jasa dalam memenuhi harapan pelanggannya secara konsisten. ${ }^{7}$

Kualitas layanan mencerminkan perbandingan antara tingkat layanan yang diberikan perusahaan dibandingkan dengan ekspektasi/harapan pelanggan Faktor utama yang mempengaruhi kualitas layanan yaitu jasa yang diharapkan dan jasa yang dipersepsikan.Kualitas layanan diwujudkan melalui pemenuhan kebutuhan dan keinginan pelanggan serta ketepatan penyampaiannya dalam mengimbangi atau melampaui harapan pelanggan. Mengevaluasi jasa yang bersifat intangible, konsumen umumnya menggunakan beberapa atribut atau faktor yang merupakan elemen-elemen layanan jasa dalam menciptakan layanan yang berkualitas 8

\section{a. Keterandalan (Reliability)}

Pemasar dituntut untuk menyediakan produk yang handal.Produk jangan sampai mengalami kerusakan/kegagalan.

\section{b.Cepat Tanggap (Responsiveness)}

Anggota perusahaan juga harus memperhatikan janji spesifik kepada konsumen, agar konsumen merasa puas, maka karyawan harus cepat tanggap akan kebutuhan konsumen tersebut, setelah

\footnotetext{
7 Zeithamal, V, A dan B. Mary Jo. (2000). Services Marketing. Irwin.Mc. GrawHill.

${ }^{8}$ Umar, H. 2003. Metode Riset : Perilaku Konsumen Jasa. Jakarta: Ghalia Indonesia, hal.135
} 
mengetahui apa yang dibutuhkan konsumen, dengan cepat dan tepat karyawan harus membantu konsumen tersebut dalam memenuhi kebutuhannya. Unsur lain yang juga penting dalam elemen cepat tanggap ini adalah anggota perusahaan selalu siap membantu konsumen.

\section{c. Kepastian (Assurance)}

Saat persaingan sangat kompetitif, anggota perusahaan harus tampil lebih kompeten, artinya memiliki pengetahuan dan keahlian di bidang masing-masing.Faktor security, yaitu memberikan rasa aman dan terjamin kepada konsumen merupakan hal yang penting.

\section{d. Memahami pelanggan (Empathy)}

Cara untuk mewujudkan sifat empathy, setiap anggota perusahaan hendaknya dapat mengelola waktu agar mudah dihubungi, baik melalui telepon ataupun bertemu langsung.

\section{e. Hal-hal yang terlihat (Tangible)}

Prasarana yang berkaitan dengan layanan konsumen juga harus diperhatikan oleh manajemen perusahaan.Bentuk gedung yang megah dengan segala fasilitasnya menjadi pertimbangan pelanggan dalam memilih suatu produk/jasa.Meliputi fasilitas fisik, lokasi gedung, penampilan karyawan, dan perlengkapan peralatan komunikasi.

\section{Pendidikan Sebagai Layanan Jasa}

Dipandang berdasarkan

penyelenggaraannya pendidikan termasuk kategori layanan jasa (service) yang dilaksanakan oleh lembaga penyelenggara pendidikan atau satuan pendidikan bagi dan untuk kepentingan masyarakat. Layanan (services) memiliki arti yang berbeda-beda, tergantung pada konteksnya. Kata jasa (service) memiliki beberapa arti, mulai dari pelayanan pribadi (personal service) sampai pada jasa sebagai suatu produk. Pendidikan merupakan layanan yang sifatnya diperuntukan untuk publik, maka orientasi layanan pendidikan pun mengarah pada masyarakat umum.

Dikutip dari Keputusan MenPan No.63 tahun 2003, pelayanan publik dapat diartikan sebagai pemberian layanan (melayani) keperluan orang atau masyarakat yang mempunyai kepentingan pada organisasi itu sesuai dengan aturan pokok dan tata cara yang telah ditetapkan. Pendidikan sebagai produk jasa merupakan sesuatu yang tidak berwujud akan tetapi dapat memenuhi kebutuhan konsumen yang diproses dengan menggunakan atau tidak menggunakan bantuan produk fisik dimana proses yang terjadi merupakan interaksi antara penyedia 
jasa dengan pengguna jasa yang mempunyai sifat yang tidak mengakibatkan peralihan hak atau kepemilikan. Dengan demikian dapat dikatakan bahwa pendidikan merupakan layanan publik yang memberikan layanan atau menghasilkan jasa bagi publik atau konsumen

Kegiatan penyelenggaraan pendidikan mulai dari tingkat dasar sampai dengan perguruan tinggi pada dasarnya adalah kegiatan atau industri jasa, yaitu memberikan layanan jasa pendidikan kepada murid/siswa sebagai pelanggan. Penyelenggaraan pendidikan mulai dari tingkat dasar sampai dengan perguruan tinggi, selayaknya mencermati kualitas layanan yang diberikan kepada siswa dan atau stakeholdersnya. Kegiatan pendidikan, tidak hanya diorientasikan kepada hasil akhir proses pendidikan dengan melahirkan sejumlah lulusan, melainkan juga fokus perhatian harus mulai diarahkan kepada kualitas layanan dalam pelaksanaan proses belajar mengajar. Kualitas layanan pendidikan perlu diperhatikan bukan karena berpengaruh terhadap hasil pendidikan, melainkan juga penting dilihat dari aspek persaingan antar lembaga penyelenggara pendidikan untuk mendapatkan siswa baru. Diyakini, kualitas layanan akan berpengaruh terhadap animo masyarakat/siswa baru ${ }^{9}$

\section{Kualitas Layanan Administrasi}

Administrasi merupakan keseluruhan proses kerjasama antara dua orang manusia atau lebih yang didasarkan atas rasionalitas tertentu untuk mencapai tujuan yang ditentukan sebelumnya. Pada perkembangannya administrasi mempunyai pengertian sama dengan manajemen, mendorong pada produktivitas kerja, pemanfaatan SDM, dan sumber daya lain (uang, material, metode) secara terpadu, pencapaian pada tujuan melalui orang lain, dan fungsi eksekutif pemerintah. Berdasarkan pada unsur-unsur yang terdapat didalamnya maka administrasi dapat dikatakan sebagai salah satu fungsi dari organisasi.

Dengan demikian maka lembaga pendidikan termasuk di dalamnya sebagai penyelenggara kegiatan administrasi. Setiap perguruan tinggi baik universitas, institut, sekolah tinggi, politeknik ataupun akademi mempunyai unsur pelaksana administratif. Satuan pelaksana administratif pada perguruan tinggi menyelenggarakan pelayanan teknis dan administratif yang meliputi administrasi akademik, administrasi

9 Yahya Sudarya. (2007). Service Quality Satisfaction dalam Layanan Pendidikan : Kajian Teoritis. Jurnal Pendidikan Dasar Nomor, hal. 81 
keuangan, administrasi umum, administrasi kemahasiswaan, administrasi perencanaan dan sistem informasi.

Kualitas pelayanan pelaksana administratif perguruan tinggi dapat dilihat dari beberapa segi. Penilaian dapat berasal dari segi wujud, keandalan, daya tanggap, kepastian, dan tingkat empati. Menurut wujudnya, apakah fasilitas (perlengkapan, peralatan) yang digunakan dalam pelayanan administratif itu jenisnya lengkap, jumlahnya cukup, keadaannya baik dan sesuai dengan perkembangan teknologi perkantoran. Pegawai administratif memiliki performansi yang baik, mampu, andal dan mau melaksanakan tugasnya masing - masing dengan memperhatikan prosedur dan metode yang baik dan efisien.

Melaksanakan pekerjaan secara konsisten dan akurat. Melayani pelanggan yang membutuhkan dengan cepat dan responsif. Tindakan dan penampilannya sopan dan terpelajar, menampilkan kepercayaan dan keyakinan. Menunjukkan perhatian yang tulus kepada setiap unsur yang membutuhkan pelayanannya.

Kualitas pelayanan administrasi dalam Perguruan Tinggi merupakan hal yang sangat penting, karena selain pelayanan akademik, pelayanan administrasi merupakan salah satu fungsi yang berhubungan langsung dengan penerima jasa (mahasiswa). Pelayanan administrasi universitas dapat meliputi proses registrasi mahasiswa, penentuan jadwal kuliah, pembayaran uang kuliah, dll. Seringkali ketika mendengar kata "administrasi" yang terbayang pada mahasiswa adalah sistem layanan yang birokratis, berbelit-belit, tidak jelas, sumber daya manusia yang masih belum menyadari arti pentingnya pelanggan, pengetahuan dan kemampuan yang kurang, sikap dan perilaku yang belum baik, dan hal-hal buruk lainnya. Padahal sekarang ini berlaku bahwa siapa yang mampu memberikan pelayanan terbaik sehingga memuaskan konsumen (mahasiswa), dialah yang bakal unggul.

Beberapa contoh kondisi diatas menggambarkan betapa pentingnya peningkatan kualitas administrasi lembaga pendidikan. Berdasarkan pendapat diatas dapat disimpulkan bahwa layanan administrasi akademik adalah segala bentuk kegiatan melayani pelanggan terkait dengan jasa yang berhubungan dengan akademik sesuai dengan prinsip-prinsip tertentu guna mendukung pencapaian tujuan organisasi secara efektif dan efisien.

\section{Hubungan Kualitas Layanan Akademik Dengan Kepuasan Mahasiswa}

Kualitas pendidikan tinggi harus didasarkan pada empat pilar pokok sumber 
daya di bidang pendidikan tinggi, yaitu sumber daya fisik (physical resources), keuangan (financial resources), informasi (information resources), dan sumber daya manusia (human resources) ${ }^{10}$.

Konsep kualitas pelayanan yang sangat popular adalah konsep ServQual yang dikembangkan oleh Parasuraman, Berry dan Zeithaml sejak 15 tahun yang lalu. Pertama kali konsep dari dimensi kualitas pelayanan diformulasikan menjadi sepuluh dimensi, kemudian disederhanakan menjadi lima dimensi ${ }^{11}$.lima faktor yang menentukan kualitas pelayanan jasa meliputi: 1) tangible (bukti langsung) mencakup fasilitas fisik, perlengkapan, pegawai, dan sarana komunikasi; 2) reliability (reliabilitas), yaitu kemampuan memberikan pelayanan yang dijanjikan dengan segera, akurat, dan memuaskan; 3) responsiveness (daya tanggap), yaitu keinginan staf membantu para pelanggan dan memberikan layanan dengan tanggap; 4) assurance (jaminan), mencakup pengetahuan, kompetensi, kesopanan, dan sifat dapat dipercaya yang dimiliki staf, bebas dari bahaya, resiko, atau keragu-raguan; (5)

${ }^{10}$ Semiawan, C. R. (1998). Pendidikan tinggi peningkatan kemampuan manusia sepanjang hayat seoptimal mungkin. Direktorat Jenderal Pendidikan Tinggi, Jakarta.

11 Irawan, H. (2002). 10 Prinsip kepuasan pelanggan. Penerbit PT. Elex Media Komputindo Gramedia, Jakarta

\section{0}

empathy (empati), meliputi kemudahan dalam menjalin relasi, komunikasi yang baik, perhatian pribadi, dan pemahaman atas kebutuhan individu para pelanggan. Bahwa uang tidak selamanya menjadi motif primer bagi seseorang, tetapi kebanggaan dan minat yang besar terhadap sesuatu akan memberi kepuasan tersendiri. Kepuasan juga dapat dipandang sebagai suatu perbandingan apa yang dibutuhkan dengan apa yang diperoleh $^{12}$.

Seseorang akan terpenuhi kepuasannya jika perbandingan tersebut cukup adil. Menurut Day Tse dan Wilton, kepuasan pelanggan merupakan respon pelanggan terhadap evaluasi ketidaksesuaian yang dirasakan antara harapan tentang kinerja dengan kinerja aktual produk yang dirasakan setelah pemakaiannya tentang apa yang dibutuhkan seseorang. Ada empat hal yang harus diperhatikan dalam peningkatan pembelajaran di perguruan tinggi (Sudarwan, 1995), meliputi: 1) metode mengajar; 2) mutu pembelajaran; 3) tidak hanya bersifat descriptive oriented tetapi mencakup penerapan ilmu yang dipelajari; dan 4) kegiatan pembelajaran membentuk

${ }^{12}$ Kotler, P.( 2000). Marketing management 9 th edition. New Jersey. Prentice Hall International. Inc. 
mahasiswa untuk dapat berdiri sendiri secara akademis melalui pola pikir analitis ${ }^{13}$.
multikolinearitas.Sementara untuk menilai goodness of fit suatu model digunakan koefisien determinasi, uji t dan uji F.

\section{METODOLOGI PENELITIAN}

Data yang digunakan dalam penelitian ini adalah data primer. Populasi dalam penelitian ini adalah seluruh mahasisw Ekonomi dan Bisnis Islam IAIN Bengkulu kurang lebih berjumlah 2.045 berdasarkan data di SIAKAD T.A 2018/2019.

Sementara pemilihan sampel
dilakukan dengan teknik purposive
sampling.Dalam hal ini responden yang dipilih adalah mahasiswa yang menggunakan jasa layanan Administrasi Akademik dan Kemahasiswaan yaitu mahasiswa aktif mulai dari semester awal sampai dengan semester akhir. Sampel yang dipilih juga sering berhubungan dengan pihak pemberi layanan administrasi di IAIN Bengkulu.

Metode analisis yang digunakan dalam penelitian ini dalah metode analisis regresi berganda.Untuk menilai pertanyaan dari kuesioner digunakan uji validitas dan uji reliabilitas. Sebelum dilakukan uji regresi berganda, terlabih dahulu dilakukan uji asumsi klasik.Uji asumsi klasik terdiri atas uji normalitas, uji heterokesdatisitas, dan uji

\footnotetext{
13 Tjiptono, F. (1998). Manajemen jasa. Edisi kedua. Penerbit Andi Offset, Yogyakarta.
}

\section{HASIL DAN PEMBAHASAN}

\section{Pembahasan dan Hasil Estimasi}

\section{a. Uji Reliabilitas}

Uji Reliabilitas adalah alat untuk mengukur suatu kuesioner yang merupakan indicator dari variabel atau konstruk ${ }^{14}$. Suatu kuesioner dikatakan reliable jika jawaban seseorang terhadap pernyataan adalah konsisten atau stabil dari waktu ke waktu. Salah satu cara untuk mengukur reliabilitas dari suatu kuesioner adalah dengan melakukan uji statistik Cronbach Alpha. Suatu konstruk atau variabel dikatak reliable jika nilai Cronbach Alpha lebih besar dari 0,6 .Dalam penelitian ini.uji statistic CronbachAlpha untuk variable- variabel diatas 0,6. Hal ini menunjukkan bahwa semua pertanyaan yang digunakan dalam kuesioner adalah reliabel.

\section{b. Uji Validitas}

Uji Validitas digunakan untuk mengukur sah atau valid tidaknya suatu kuesioner. Suatu kuesioner dikatakan valid

\footnotetext{
${ }^{14}$ Ghozali, Imam (2006). Aplikasi Multivariate dengan SPPS. BP Undip
} 
jika pertanyaan pada kuesioner mampu mengungkapkan sesuatu yang akan diukur oleh kuesioner tersebut. Jadi validitas ingin mengukur apakah pertanyaan dalam kuesioner yang sudah dibuat betul-betul dapat mengukur apa yang hendak kita ukur. Disajikan hasil uji Validitas untuk masingmasing indikator terhadap variabel variable menunjukkan hasil yang signifikan. Hal ini berarti bahwa masing-masing indikator pertanyaan untuk variabel Kualitas Layanan Akademik adalah valid.

\section{c. Uji Normalitas}

Uji normalitas digunakan untuk menguji apakah dalam model regresi baik variable independent maupun varabel dependen memiliki distribusi data normal atau tidak.Model regresi yang baik adalah yang memiliki distribusi data normal atau mendekati normal. ${ }^{15}$ Dalam penelitian ini uji normalitas menggunakan analisis grafis. Berikut disajikan hasil dari KolmogorovSmirnov test dalam gambar 4.1.

Gambar 4.1

\section{Hasil Uji Normalitas}

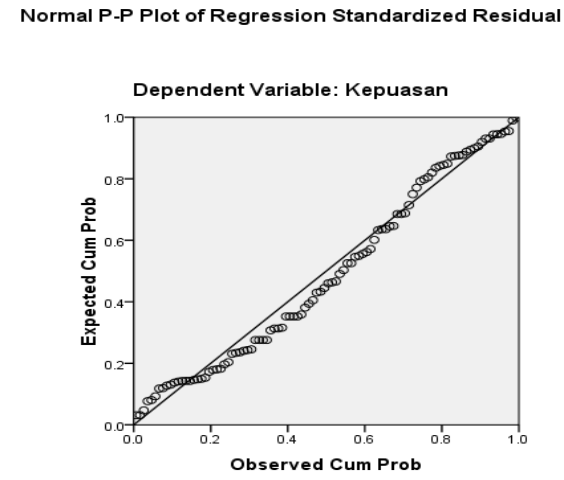

Sumber: Hasil SPSS

Pada grafik normal probability plots titiktitik menyebar berhimpit di sekitar diagonal dan hal ini menunjukkan bahwa residual terdistribusi secara normal.

\section{d. Uji Heteroskesdatisitas}

Uji heteroskedastisitas bertujuan untuk menguji apakah dalam model regresi terjadi ketidaksamaan variance dari residual satu pengamatan ke pengamatan yang lain. Jika variance dari residual satu pengamatan ke pengamatan yang lain tetap, maka disebut homoskedastisitas. Model yang baik adalah yang homoskedastisitas

Pada penelitian ini untuk menguji terjadinya heteroskedastisitas atau tidak dengan menggunakan analisis grafis.Deteksi ada atau tidaknya heteroskedastisitas dapat dilakukan dengan melihat ada tidaknya pola tertentu dalam scatterplot antara variable dependen (ZPRED) dengan residualnya (SRESID). Dasar analisis grafis adalah jika ada pola tertentu seperti titik-titik yang ada
${ }^{15}$ Ibid co id 
membentuk pola tertentu yang teratur maka mengindikasikan heteroskedastisitas.

Jika tidak ada pola yang jelas, serta titik-titik yang menyebar diatas dan di bawah angka nol pada sumbu Y maka mengindikasikan tidak terjadinya heteroskedastisitas.

\section{Gambar 4.2}

\section{Uji Heteroskesdatisitas}

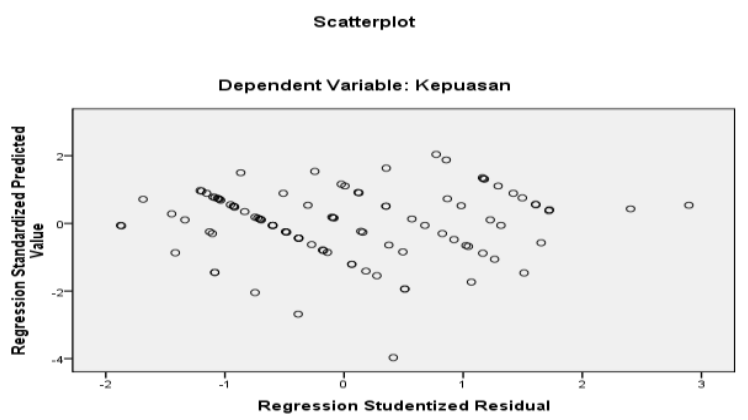

Sumber: Hasil SPSS

Berdasarkan gambar di atas terlihat bahwa titik-titik yang ada tidak membentuk suatu pola tertentu atau titik-titik yang ada menyebar diatas dan dibawah angka nol sehingga bisa disimpulkan bahwa dalam penelitian ini model regresi yang dipakai tidak mengalami heteroskedastisitas.

\section{e. Uji Multikolinearitas}

Uji Multikolinearitas bertujuan untuk menguji apakah model regresi ditemukan adanya korelasi antar variable independen. Model regresi yang baik seharusnya tidak terjadi korelasi di antara variabel bebas. Variabel orthogonal adalah variabel bebas yang nilai korelasi antar sesama variabel bebas sama dengan nol. Hasil SPSS dari uji multikolinearitas diperoleh hasil bahwa semua variabel independen dari model regresi tidak terdapat multikolinearitas yang ditunjukkan oleh nilai VIF yang dibawah 10 dan nilai tolerance yang lebih besar dari 0,1. Ini menunjukkan bahwa model regresi ini layak untuk digunakan karena tidak terdapat variabel yang mengalami multikolinearitas.

\section{f. Koefisien Determinasi}

Koefisien Determinasi $\left(\mathrm{R}^{2}\right)$ mengukur seberapa jauh kemampuan model dalam menerangkan variasi variabel dependen.Nilai koefisien determinasi adalah diantara nol dan satu.Nilai $\mathrm{R}^{2}$ yang kecil berarti kemampuan variabel independent dalam menerangkan variabel dependen sangat terbatas. Nilai yang mendekati satu berarti variabel independent memberikan hampir semua informasi yang dibutuhkan untuk memprediksi variasi variabel dependen.

Dalam perhitungan statistik ini nilai $\mathrm{R}^{2}$ yang digunakan adalah adjusted $R$ square. Adjusted $R$ square adalah suatu indikator yang digunakan untuk mengetahui pengaruh 
penambahan suatu variabel independent ke dalam suatu persamaan regresi. Nilai adjusted $\mathrm{R}^{2}$ telah dibebaskan dari pengaruh derajat kebebasan (degree of freedom) yang berarti nilai tersebut telah benar-benar menunjukkan bagaimana pengaruh variabel independen terhadap variabel dependen. Berikut adalah koefisien determinasi dari penelitian ini yang disajikan dalam tabel 4.6

Tabel 4.1

\section{Koefisien Determinasi}

Model Summary

\begin{tabular}{|c|c|c|c|c|c|}
\hline $\begin{array}{c}\text { Mo } \\
\text { del }\end{array}$ & \multicolumn{2}{|c|}{$\mathrm{R}$} & $\mathrm{R}$ Square & $\begin{array}{c}\text { Adjusted R } \\
\text { Square }\end{array}$ & $\begin{array}{c}\text { Std. Error of } \\
\text { the Estimate }\end{array}$ \\
\hline 1 & $\begin{array}{c}.73 \\
6^{\mathrm{a}}\end{array}$ & .541 & .517 & 1.18147 \\
\hline
\end{tabular}

Sumber: Hasil SPSS yang dikompilasi

Dari tabel di atas bahwa nilai adjusted $\mathrm{R}$ square adalah sebesar 0.517 menunjukkan bahwa variasi variabel independen mampu menjelaskan 51,7\% variasi variabel dependen, sedangkan sisanya yaitu sebesar $48.3 \%$ dijelaskan oleh variabel lain diluar variabel independent. Nilai koefisien korelasi (R) sebesar 0.736 menunjukkan bahwa kuat hubungan antara variabel independen terhadap variabel dependen.
Hasil perhitungan uji dalam tabel 4.1 diatas diperoleh hasil koefisien korelasi atau $\mathrm{R}$ sebesar 0.517 hal ini menunjukkan bahwa pengaruh kualitas layanan akademik dan administrasi terhadap kepuasan mahasiswa Fakultas Ekonomi dan Bisnis Islam positif, yaitu sebesar 51,7 sisanya sebesar $48.3 \%$ dipengaruhi oleh variabel lain yang tidak diteliti dalam penelitian ini.

\section{g. Uji F}

Uji statistik $F$ pada dasarnya menunjukkan apakah semua variabel independent yang dimasukkan dalam model mempunyai pengaruh secara simultan terhadap semua variabel dependen. Berikut hasil Uji $\mathrm{F}$ yang diolah menggunakan SPSS yang disajikan dalam Tabel 4.2

\section{Tabel 4.2}

\section{Uji F}

\begin{tabular}{|c|c|c|}
\hline Model & $F$ & Sig. \\
\hline Regression & 22.183 & $.000^{\mathrm{a}}$ \\
\hline
\end{tabular}

Sumber: Hasil SPSS yang dikompilasi

Dari hasil perhitungan di atas dapat dilihat bahwa nilai signifikansi adalah sebesar 0,000 dan nilai $\mathrm{F}$ hitung sebesar 22.183. Dasar pengambilan keputusan adalah tingkat signifikansinya sebesar $5 \%$ atau 0,05 . Karena nilai signifikansi lebih kecil dari 0,05 maka menunjukkan adanya pengaruh Kualitas Layanan Administrasi di IAIN Bengkulu 
terhadap Kepuasan Mahasiswa Fakultas

Ekonomi dan Bisnis Islam secara simultan.

Dasar pengambilan keputusan yang lain adalah nilai $\mathrm{F}$ hitung harus lebih besar dari $\mathrm{F}$ tabel untuk menentukan adanya pengaruh dari variabel independent terhadap variabel dependen. Dari perhitungan di atas dapat dilihat bahwa nilai $\mathrm{F}$ hitung yang sebesar 16.279 yang lebih besar dari nilai $\mathrm{F}$ tabel yang 3,32 maka dapat disimpulkan bahwa Kualitas Layanan Administrasi di IAIN Bengkulu berpengaruh secara simultan terhadap Kepuasan Mahasiswa Fakultas Ekonomi dan Bisnis Islam.

\section{h. Uji t}

Uji statistik $t$ pada dasarnya menunjukkan seberapa jauh pengaruh satu variabel independen secara parsial didalam menerangkan variasi variabel dependen. Berikut hasil SPSS dari Uji t yang disajikan dalam tabel 4.8

Tabel 4.3

Uji t

\begin{tabular}{|l|r|r|}
\hline \multicolumn{1}{|c|}{ Model } & \multicolumn{1}{c|}{ T } & \multicolumn{1}{c|}{ Sig. } \\
\hline (Constant) & 2.050 & .043 \\
\hline Bukti Fisik & 3.430 & .001 \\
\hline Kehandalan & 2.318 & .023 \\
\hline Daya Tanggap & 2.688 & .008 \\
\hline Jaminan & 3.959 & .000 \\
\hline Kepedulian & 2.098 & .039 \\
\hline
\end{tabular}

Sumber: Hasil SPSS yang dikompilasi
Dari tabel diatas dapat dilihat bahwa semua variable memiliki nilai $t$ hitung yang lebih besar dari t tabel $(1,96)$, dan tingkat signifikansi yang lebih kecil dari 0,05. Hal ini menunjukkan bahwa secara parsial setiap variabel independen mempengaruhi variabel dependen.

\section{i. Persamaan Regresi}

Berikut disajikan hasil perhitungan koefisien regresi dengan menggunakan SPSS 16 mengenai persamaan regresi dari penelitian ini.

Setelah semua asumsi klasik terpenuhi maka dapat dilakukan analisis regresi linear berganda. Model analisis regresi berganda digunakan untuk mengetahui pengaruh kualitas pelayanan (Reliability, Responsiveness, Emphaty, Assurance dan Tangible) terhadap kepuasan mahasiswa. Rangkuman hasil analisis dapat di lihatl berikut ini

$$
\begin{gathered}
Y=2.748+0.271 X_{1}+0.197 X_{2}+0.201 X_{3} \\
+0.36 X_{4}+0.165 X_{5}
\end{gathered}
$$

Dari persamaan regresi diatas diketahui bahwa nilai koefisien regresi adalah sebagai variable bebas kualitas layanan akademik bertanda positif terhadap variable terikat (kepuasan mahasiswa)

Hasil dari penelitian ini dapat simpulkan bahwa tanggapan mahasiswa tentang kualitas layanan akademik intitut terhadap Mahasiswa 
Fakultas Ekonomi dan Bisnis Islam Untuk variabel kualitas layanan akademik koefisien regresinya adalah semuanya positif, hal ini dapat diartikan apabila kualitas layanan akademik semakin baik, maka kepuasan mahasiswa akan meningkat. Ini berarti bahwa keberhasilan sebuah lembaga sangat ditentukan oleh mutu layanan yang diberikan. Pelayanan yang bermutu dapat diidentifikasikan melalui kepuasan pelanggan

\section{Simpulan dan Implikasi Kebijakan}

\section{a. Ringkasan Penelitian}

Penelitian ini mencoba untuk menganalisis variabel-variabel kualitas layanan yang dapat mempengaruhi kepuasan mahasiswa Fakultas Ekonomi dan Bisnis Islam. Pada penelitian ini digunakan lima variable, yaitu bukti fisik, kehandalan layanan, daya tangkap, jaminan, kepedulian. hipotesis yang dikembangkan dalam penelitian ini, yaitu : Semakin baik kualitas layanan administrasi akademik di IAIN Bengkulu maka kepuasan mahasiswa khusunya Fakultas Ekonomi dan Bisnis Islam akan semakin tinggi.peningkatan dalam pelayanan administrasi akademik dapat membatu keberhasilan sebuah lembaga, keberhasilan lembaga sangat ditentukan oleh mutu layanan yang diberikan. Pelayanan yang bermutu dapat diidentifikasikan melalui kepuasan pelanggan (mahasiswa) sesuai dengan Standar ISO disebutkan pada salah satu prinsip bahwa pengukuran kepuasan pelanggan wajib dilakukan sebagai umpan balik dari pelanggan terhadap sistem yang diterapkan. Ini berarti bahwa keberhasilan sebuah lembaga sangat ditentukan oleh mutu layanan yang diberikan. Pelayanan yang bermutu dapat diidentifikasikan melalui kepuasan pelanggan. Sebagai lembaga pendidikan maka proses akademik merupakan proses inti, oleh karena itu pengukuran kepuasan pelanggan pada proses ini wajib dilakukan secara periodik. Berlandaskan pemahamam mutu diatas, dapat dikatakan bahwa saat ini pendidikan bukan lagi sebatas kemampuan untuk menghasilkan lulusan yang diukur secara akademik, tetapi sudah mengarah pada suatu bentuk kualitas pendidikan secara menyeluruh (Total Quality Education) yang berorientasi pada kepuasan pelanggan.

Hasil dari perhitungan menunjukkan bahwa variabel kualitas layanan administrasi akademik dan kemahasiswaan dan berpengaruh positif terhadap kepuasan mahasiswa Fakultas Ekonomi dan Bisnis Islam. Hal ini dapat dilihat dari nilai koefisien regresi untuk variable-variable berikut fasilitas (bukti Fisik) $\mathrm{X}_{1}$ sebesar 0.271, 
kehandalan dalam memberikan pelayanan $\mathrm{X}_{2}$ sebesar 0.197, daya tanggap $X_{3}$ sebesar 0.201, kenyaman mahasiswa mendapatkan pelayanan (Jaminan) $\mathrm{X}_{4}$ sebesar 0.316 dan kepedulian $\mathrm{X}_{5}$ sebesar 0.164 ini menunjukan kualitas pelayanan berpengaruh sangat nyata terhadap kepuasan mahasiswa. Dengan kata lain tanpa adanya perhatian terhadap kualitas pelayanan yang baik akan mengakibatkan rendahnya kepuasan. Strategi yang paling tepat dalam meningkatkan kualitas pelayanan akademik pada perguruan tinggi adalah dengan meningkat variabel yang ada pada kualitas pelayanan yaitu Bukti langsung (tangibles), Kehandalan (reliability), Daya tanggap (responsivess), Jaminan (assurance), Empati (emphaty) dengan dibuktikan dengan ketersuaian yang ada dilapangan harapan dan kenyataan.Pelayanan akademik dikatakan berkualitas/bermutu apabila sesuai dangankebutuhan-kebutuhan pelangganya. Senada dengan yang disampaikan Lupiyoadi kualitas pelayanan akademik adalah nilai yang diberikan oleh pelanggan sejauhmana layanan akademik Pelanggan dalam hal ini mahasiswa yang akan mengatakan pelayanan akademik berkualitas apabila sesuai dengan spesipikasi mereka. Pelayanan akademik yang berkualitas akan mengarah pada kepuasan akademik mahasiswa sebagai pelanggan primer.
Secara parsial (t) maupun secara simultan terhadap variabel dependen. Hal ini dapat dilihat dari tingkat signifikansi untuk variabel tersebut yang lebih kecil dari 0,05. dapat ditarik kesimpulan: Jadi dapat disimpulkan bahwa variabel kualitas pelayanan $(\mathrm{X})$ berpengaruh secara signifikan terhadap kepuasan mahasiswa (Y) pada layanan akademik. Kepuasan pengguna jasa pendidikan menjadi sangat penting bagi kemajuan sebuah institusi pendidikan, sebagaimana bagi sebuah perguruan tinggi maka kepuasan mahasiswa sebagai pengguna jasa utama menjadi tonggak bagi keberlangsungan suatu perguruan tinggi. Hal ini dikarenakan kepuasan mahasiswa akan berdampak pada loyalitasnya terhadap perguruan tinggi tersebut. Seorang pengguna jasa (mahasiswa) yang loyal akan menjadi aset yang sangat bernilai bagi suatu perguruan tinggi, karena mahasiswa akan bersedia mempromosikan perguruan tinggi tersebut kepada orang lain, memberikan umpan balik positif terhadap institusi pendidikan, mengurangi pengaruh serangan dari para competitor institusi sejenis (bergaining position), serta meningkatkan citra positif dari institusi tersebut.

Nilai adjusted $\mathrm{R}$ square pada penelitian ini adalah sebesar 0,517. Hal ini berarti bahwa variasi dari variabel kualitas 
layanan akademik dan kualitas layanan administrasi mampu menjelaskan sebesar $51,7 \%$ dari variasi variabel kepuasan mahasiswa Fakultas Ekonomi dan Bisnis Islam.

Dinarasikan. Dari hasil penelitian ini jika diterapkan akan pelayanan akademik yang berkualitas, Mahasiswa merasa puas dengan layanan akan menghasilakan banyak keuntungan antara lain kemampuan mahasiswa akan terjamin baik dan perguruan tinggi akan terkenal dan menjadi rebutan. Sebaliknya ketidakpuasan mahasiswa akan menmbulkan kerugian. Pendapat lain mengungkapkan kepuasana akademik mahsiswa akan layanan akademik yang diterimanya sesuai antara harapan dan kinerja layanan yang diterimanya.

\section{KESIMPULAN}

Kesimpulan dalam penelitian ini adalah "Semakin baik kualitas layanan administrasi akademik dan kemahasiswaan maka kepuasan mahasiswa Fakultas Ekonomi dan Bisnis Islam akan semakin tinggi”.

Berdasarkan hasil perhitungan sebelumnya, diperoleh hasil bahwa hipotesis diterima. Ini memperkuat dari penelitian sebelumya mengenai kualitas layanan akademik. Ini sesuai dengan penelitian yang 88 dilakukan oleh Tuti Wahyuni (2013) dan Novi Rustiana Dewi (2013) dan Yanisma menunjukkan bahwa semakin baik kualitas layanan yang diberikan pihak universitas maka kepuasan mahasiswa semakin tinggi dengan kajian teori Yamit (2004) Kepuasan pelanggan tercapai bila kebutuhan, keinginan, dan harapan pelanggan terpenuhi. Harapan pelanggan dapat diidentifikasi secara tepat apabila perusahaan mengerti persepsi pelanggan terhadap kepuasan. Mengetahui persepsi pelanggan terhadap kepuasan sangatlah penting, agar tidak terjadi kesenjangan

\section{Saran}

Tujuan dari penelitian ini adalah untuk meningkatkan pelayanan agar mahasiswa puas mendapatkan pelayanan akademik, dari hasil penelitian diperoleh bahwa variable Kualitas Layanan Administrasi Akademik dan Kemahasiswaan berpengaruh secara positif terhadap Kepuasan Mahasiswa.

Berdasarkan hasil analisis menunjukkan bahwa dimensi bukti langsung, keandalan, daya tanggap, jaminan dan empati berpengaruh terhadap kepuasan mahasiswa, untuk itu perlu memperbaiki peralatan dan perlengkapan layanan administrasi akademik, peningkatan kondisi penampilan fisik ruangan pelayanan administrasi akademik, penampilan 
karyawan yang rapi, memberikan pengarahan kepada karyawan administrasi akademik dan kemahasiswaan sehingga karyawan dapat memberikan pelayanan yang lebih baik, selalu siap dalam membantu mahasiswa melakukan urusan administrasi akademik.

Memberikan sosialisasi bagi karyawan administrasi akademik tentang pentingnya pemberian pelayanan prima terhadap mahasiswa melalui karyawan yang dapat dipercaya dan bertanggung jawab, karyawan yang selalu bersikap ramah dan sopan dalam memberikan pelayanan, dan karyawan yang menguasai peraturan serta prosedur pemberian layanan, karyawan yang mampu berkomunikasi baik dengan kepada mahasiswa terkait dengan kegiatan administrasi akademik karena mahasiswa akan merasa lebih aman dalam melakukan urusan administrasi akademik sehingga mahasiswa merasa semua kebutuhan yang diinginkan mampu terpenuhi dengan maksimal.

Apabila penilaian mahasiswa terhadap dimensi kualitas pelayanan yangd iberikan kurang baik maka berdampak pada kepuasan mahasiswa Peneliti mengajukan saran-saran bagi penelitian selanjutnya, dimana dalam penelitian ini sampel yang digunakan sangat terbatas dan alat analisis yang digunakan sudah sering digunakan, maka dalam penelitian selanjutnya diharapkan dapat menggunakan sampel yang lebih banyak dan menggunakan alat analisis yang terbaru.

Saran bagi pihak pengelola bagian akademik diharapkan ada kerjasama atau pengertian baik dari pengelola administrasi dan mahasiswa demi memenuhi standarisasi pelayanan yang prima dan terciptanya hubungan harmonis antara karyawan administrasi dengan mahasiswa dan hendaknya para mahasiswa sebagai pengguna layanan/ jasa administrasi menghormati segala kebijakan administrasi akademik dan kemahasiswaan secara dewasa dan bijaksana 


\section{DAFTAR PUSTAKA}

Endang, Fatmawati. (2003). Analisis Kualitas

Pelayanan Pada Bagian Administrasi Fakultas Ekonomi UNDIP. Tesis. Universitas Diponegoro.

Fandy Tjiptono. (2002). Strategi Pemasaran. Yogyakarta: Penerbit Andi.

Ghozali, Imam (2006). Aplikasi Multivariate dengan SPPS. BP Undip

Irawan, H. (2002). 10 Prinsip kepuasan pelanggan. Penerbit PT. Elex Media Komputindo Gramedia, Jakarta

Kotler, P.( 2000). Marketing management 9 th edition. New Jersey. Prentice Hall International.Inc.

Kotler, Philip. 1997, Manajemen Pemasaran :Analisis, Perencanaan, Implementasi dan Kontrol, Ed. 9, Jilid 1, PT Prenhallindo, Jakarta

Semiawan, C. R. (1998). Pendidikan tinggi peningkatan kemampuan manusia sepanjang hayat seoptimal mungkin. Direktorat Jenderal Pendidikan Tinggi, Jakarta.

Tjiptono, F. (1998). Manajemen jasa. Edisi kedua. Penerbit Andi Offset, Yogyakarta.
Umar, H. 2003. Metode Riset : Perilaku Konsumen Jasa. Jakarta: Ghalia Indonesia

Wahyuni Tuti (2013).Kepuasan Mahasiswa Atas kualitas Pelayanan AdministrasiJurnal BISE Vol 1 No 1 Diakses dari :http://portalgaruda.org/article.php.

Yahya Sudarya. (2007). Service Quality Satisfaction dalam Layanan Pendidikan : Kajian Teoritis. Jurnal Pendidikan Dasar Yanisma.(2010) Analisis Kepuasan Mahasiswa Terhadap Kualitas Layanan Pada Biro Admnistrasi Akademik Kemahasiwaan (Studi Kasus Mahasiswa Politeknik Negeri Bengkalis) DiaksesDari http://p3m.polbeng.ac.id/dataq/file_conte $\underline{\text { nt/File }}$

Yamit, Z. 2004. Manajemen Kualitas: Produk Dan Jasa. Yogyakarta: Ekonisia (Studi Kasus Mahasiswa Politeknik Negeri Bengkalis) Diakses Dari http://p3m.polbeng.ac.id/dataq/file_conte $\underline{\text { nt/File }}$ 
Zeithamal, V, A dan B. Mary Jo. (2000).

Services Marketing. Irwin.Mc. GrawHill. I 